\title{
Inhibition of biofilm formation and swarming of Bacillus subtilis by (5Z)-4-bromo-5-(bromomethylene)- 3-butyl-2(5H)-furanone
}

\author{
D. Ren ${ }^{1}$, J.J. Sims ${ }^{2}$ and T.K. Wood ${ }^{1}$ \\ ${ }^{1}$ Departments of Chemical Engineering and Molecular \& Cellular Biology, University of Connecticut, Storrs, \\ and ${ }^{2}$ Department of Plant Pathology, University of California, Riverside, USA
}

2001/307: received 26 October 2001 and accepted 7 January 2002

D. REN, J.J. SIMS AND T.K. WOOD. 2002.

Aims: (5Z)-4-Bromo-5-(bromomethylene)-3-butyl-2(5H)-furanone (furanone) of the marine alga Delisea pulchra was synthesized, and its inhibition of swarming motility and biofilm formation of Bacillus subtilis was investigated.

Methods and Results: Furanone was found to inhibit both the growth of B. subtilis and its swarming motility in a concentration-dependent way. In addition, as shown by confocal scanning laser microscopy, furanone inhibited the biofilm formation of $B$. subtilis. At $40 \mu \mathrm{g} \mathrm{ml}^{-1}$, furanone decreased the biofilm thickness by $25 \%$, decreased the number of water channels, and reduced the percentage of live cells by $63 \%$.

Conclusions, Significance and Impact of the Study: Natural furanone has potential for controlling the multicellular behaviour of Gram-positive bacteria.

\section{INTRODUCTION}

The incidence of Gram-positive bacterial infections has increased significantly in recent years. For example, the number of Gram-positive infections per 1000 hospital admissions increased sixfold in the UK from 1985 to 1996 , while the number of Gram-negative infections increased fourfold in the same period (Crowe et al. 1998). In addition, Gram-positive bacteria were responsible for more than $60 \%$ of the nosocomial bloodstream infections in the United States, while Gram-negative bacteria were responsible for only $27 \%$ of such infections (Edmond et al. 1999). Since antibiotics are not equally efficient for Gram-negative and Gram-positive bacteria, the appearance of antibiotic-resistant Gram-positive bacteria poses a serious problem (Edmond et al. 1999). Furthermore, Gram-positive biofilms cause significant corrosion problems, such as that of Desulfosporosinus orientis which corrodes mild steel seriously (Kumar et al. 1999). Therefore, it would be advantageous to have additional Gram-positive antimicrobials.

Swarming and biofilm formation are strongly related to disease (Allison et al. 1992; Elvers and Lappin-Scott 2000).

Correspondence to: Dr T.K. Wood, Departments of Chemical Engineering and Molecular E Cellular Biology, University of Connecticut, 191 Auditorium Road, Storrs, CT 06269-3222, USA (e-mail: tmood@engr.uconn.edu).
Although the mechanisms of these two important multicellular activities have been investigated (Allison and Hughes 1991; Davies et al. 1998; Kolter and Losick 1998), techniques for efficient control are still insufficient.

Swarming exists for both Gram-positive and Gramnegative bacteria, and many species have been shown to exhibit this motility, including Proteus mirabilis and Bacillus subtilis (Allison and Hughes 1991). Swarming has three stages: (i) recognition of appropriate environmental signals with the formation of elongated and hyperflagellated swarming cells; (ii) co-ordinated movement of the swarming cells; (iii) consolidation to vegetative cells and initiation of a new round of swarming (Allison and Hughes 1991). It occurs at specific surface viscosities (e.g. $0 \cdot 7-0.8 \%$ agar plates for Serratia marcescens) and nutrient conditions (Allison and Hughes 1991; Fujikawa 1994). In the laboratory, swarming can take place on semi-solid agar plates with a speed as high as $16 \mu \mathrm{m} \mathrm{s}^{-1}$ (Allison and Hughes 1991). Bacillus subtilis has been shown to exhibit swarming motility that is affected by conditions such as nutrient status (Fujikawa 1994), surface wetness (Mendelson and Salhi 1996), and the existence of chemicals such as surfactants and detergents (Thampuran and Surendran 1996).

Biofilm formation is a form of multicellular behaviour that is ubiquitous in aquatic environments, and $B$. subtilis has been shown to form biofilms on metal surfaces (Jayaraman 
et al. 1997). By attachment to submerged surfaces and production of microbial products such as polysaccharides (Elvers and Lappin-Scott 2000), bacteria are able to form biofilms with complex, three-dimensional structures. The top or base of the biofilm has the highest cell density, and water channels (lateral variation) exist for the transport of nutrients and waste (Lawrence et al. 1991; Kolter and Losick 1998; Elvers and Lappin-Scott 2000).

It has been found that cell communication, based on density-dependent chemical inducers termed quorum sensing, is important for bacterial multicellular behaviour such as swarming (Eberl et al. 1996b) and biofilm formation (Davies et al. 1998). Cell communication in quorum sensing is based on small molecules, called autoinducers (AI), such as acylated homoserine lactones for Gramnegative bacteria and peptide signalling molecules for Gram-positive bacteria (Bassler 1999). Quorum sensing is a complex system in which one strain may encode multiple autoinducers and may have interspecies signalling (sense the population of other bacteria). For example, Vibrio harveyi has two AI systems, AI-1 (hydroxybutanoyl-Lhomoserine lactone) (Cao et al. 1989) for species-specific quorum sensing, and AI-2 (furanone-related compound furanosyl borate diester, derived from 4,5-dihydroxy-2,3pentanedione (Schauder et al. 2001; Chen et al. 2002) for non-specific quorum sensing (Bassler et al. 1997; Surette and Bassler 1998; Freeman and Bassler 1999). Whilst the AI-1 system is exclusive to Gram-negative bacteria, the AI-2 system is found in both Gram-positive (including B. subtilis (Surette et al. 1999)) and Gram-negative bacteria (Surette et al. 1999).

Recently, several natural furanones produced by the seaweed Delisea pulchra have been found to reduce the growth rate of Gram-positive bacteria, including Staphylococcus aureus and Staph. epidermidis, but to have no effect on the growth of mammalian cells (Kjelleberg 1998). It has also been shown that such furanones can inhibit several activities of Gram-negative bacteria without affecting the growth rate. These include the swarming of Proteus mirabilis (Gram et al. 1996), the biofilm formation of Escherichia coli (Ren et al. 2001) and siderophore synthesis of Pseudomonas putida F1 (Ren et al. unpublished). It is likely that these furanones can inhibit the multicellular behaviour of Gram-negative bacteria by suppression of the autoinduction circuit (Givskov et al. 1996), and furanone has been shown to inhibit quorum sensing based on either the AI-1 or AI-2 system (Ren et al. 2001).

In this paper, the antimicrobial properties of furanone were investigated by examining its impact on the growth rate, swarming motility and biofilm formation of B. subtilis. This is one of the first reports of the antibiotic effect of furanone on $B$. subtilis and its effect on the swarming and biofilm formation of a Gram-positive bacterium.

\section{MATERIALS AND METHODS}

\section{Bacterial strains and culture media}

Bacillus subtilis BE1500 (Nagarajan et al. 1992) with plasmid pBE92 (henceforth B. subtilis) was obtained from E.I. du Pont de Nemours Inc. (Wilmington, DE, USA) and was grown at $37^{\circ} \mathrm{C}$ in $\mathrm{LB}$ medium supplemented with kanamycin at $50 \mu \mathrm{g} \mathrm{ml}^{-1}$. pBE92 is a derivative of pBE60 that encodes kanamycin resistance (Nagarajan et al. 1992) and was used to avoid contamination while culturing the Bacillus strain.

LB medium supplemented with $0 \cdot 4 \%$ agar $(20 \mathrm{ml})$ was used to study swarming in $100 \times 15 \mathrm{~mm}$ Petri dishes which were dried for $2 \mathrm{~h}$ at $30^{\circ} \mathrm{C}$. The furanone was dissolved in dichloromethane at various concentrations (119-2380 $\mu \mathrm{g} \mathrm{ml}^{-1}$ ) and added to the top of the agar plate in $40 \mu \mathrm{l}(40 \mu \mathrm{l}$ dichloromethane was added to all plates, including those with no furanone). To determine whether the furanone would form a gradient in the agar plate by diffusion, or remain at the agar surface, tests were conducted by dissolving hydrophobic ink in dichloromethane and adding it to the top of agar plates. It was found that the dichloromethane did not diffuse into the agar. Hence, the concentration of furanone was based on the area of this layer but not the volume. After adding the furanone, swarming plates were dried for another $3 \mathrm{~h}$ at $30^{\circ} \mathrm{C}$. Bacillus subtilis cells were inoculated with toothpicks at the centre of the furanone-containing area from 2-day-old-streaks on LB medium supplemented with $50 \mu \mathrm{g} \mathrm{ml}^{-1}$ kanamycin. The swarming colonies were grown at $37^{\circ} \mathrm{C}$. At least seven plates were used for each furanone concentration.

\section{Furanone synthesis}

4-Bromo-5-(bromomethylene)-3-butyl-2(5H)-furanone (Fig. 1) was synthesized as reported previously (Beechan and Sims 1979), with the exception that the furanone was purified using column chromatography with hexane and ethyl acetate at a ratio of 100:1 $(2.5 \times 60 \mathrm{~cm}$ column, Spectrum Chromatography, Houston, TX, USA). The structure was verified with ${ }^{1}$ H-NMR (Bruker DRX-400 MHz, Billerica, MA, USA; $6 \cdot 24$ single peak, vinylidene; 2.39 triple peaks, coupling constant $\mathrm{J} 7.2 \mathrm{~Hz}$, allylic methylene; 0.93 triple peaks, coupling constant $\mathrm{J} 7 \cdot 2 \mathrm{~Hz}$, terminal methyl), mass spectroscopy (Series II 5890, Hewlett Packard, San Fernando, CA, USA; molecular ion peaks $\left.\mathrm{M}^{+}: 308,310,312\right)$ and infrared spectroscopy (Nicolet-Magna-IR 560, Madison, WI, USA; reciprocal absorbing wavelength: 2958, 1793, 1610, $1276,1108,1030 \mathrm{~cm}^{-1}$ ) by comparing with literature values (Beechan and Sims 1979; Manny et al. 1997). Routinely, the furanone product was verified by comparing with standard furanone synthesized by the method of Beechan and Sims (1979) using thin layer chromatography (hexane and ethyl acetate at a ratio of 20:, $\mathrm{R}_{\mathrm{f}}=0.8$; Silica Gel 60, F-254). 


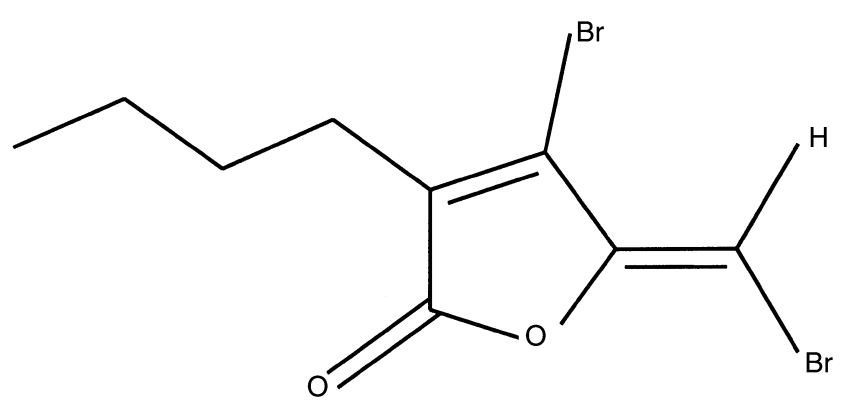

Fig. 1 Structure of (5Z)-4-bromo-5-(bromomethylene)-3-butyl$2(5 H)$-furanone

\section{Growth rate}

The growth rates in liquid cultures to which furanone had been added were measured in duplicate in $250 \mathrm{ml}$ shake flasks with LB medium $(25 \mathrm{ml})$ supplemented with $50 \mu \mathrm{g} \mathrm{ml}^{-1}$ kanamycin. The furanone was dissolved in $95 \%$ ethanol $\left(14.9 \mathrm{mg} \mathrm{ml}^{-1}\right)$ and added to each flask to give a final concentration of 10,20 and $40 \mu \mathrm{g} \mathrm{ml}^{-1}$. All of the flasks (including those with no furanone) were supplemented with the same amount of ethanol $(67 \cdot 1 \mu \mathrm{l}$ of $95 \%$ ethanol to $25 \mathrm{ml}$ medium) to eliminate the effects of the solvent.

To determine the effect of furanone on colony growth of $B$. subtilis, furanone was added to the top of the LB agar $(1.5 \%)$ plates which support growth but not swarming. Furanone was added by dissolving in dichloromethane at different concentrations in a volume of $40 \mu \mathrm{l}$. Bacillus subtilis was inoculated as in the swarming experiments. The same concentrations of furanone as those in the swarming experiments were tested.

\section{Biofilm formation}

The impact of furanone on biofilm formation was determined with SAE1018 steel coupons $(25.5 \mathrm{~mm}$ diameter and $1.2 \mathrm{~mm}$ thick, polished with $\mathrm{P} 240$ polishing paper, 3M Imperial Wetor-Dry, St Paul, MN, USA). A single coupon was placed in a $100 \times 15 \mathrm{~mm}$ Petri dish with $20 \mathrm{ml}$ LB supplemented with $50 \mu \mathrm{g} \mathrm{ml}^{-1}$ kanamycin. The furanone was dissolved in $95 \%$ ethanol $\left(14.9 \mathrm{mg} \mathrm{ml}^{-1}\right)$ and added to the culture at the start of the experiments with the final concentration of 20 or $40 \mu \mathrm{g} \mathrm{ml}^{-1}$ (the same amount of $95 \%$ ethanol, $0.6 \%$, was added to all samples, including those without furanone). Coupons were incubated at $37^{\circ} \mathrm{C}$ without shaking for 3 days, then analysed by confocal microscopy. Metal coupons with attached biofilms were removed gently from Petri dishes and immersed immediately in $0.85 \% \mathrm{NaCl}$ solution to remove the bulk of planktonic cells. The biofilm was stained with the Live/Dead Baclit bacteria viability assay kit (L-7007, Molecular Probes, Inc., Eugene, OR, USA) at a concentration of $1 \cdot 125 \mu \mathrm{l} \mathrm{ml}^{-1}$ (for both staining components, $\mathrm{A}$ and
$\mathrm{B}$, of this kit). The staining process was performed in the dark at room temperature for $30 \mathrm{~min}$ with $4 \mathrm{ml}$ staining solution for each sample.

After staining, the coupons were protected with a cover glass and observed with confocal scanning laser microscopy (MRC 600, BIO-RAD, Hercules, CA, USA) using the dual channel mode (K1/K2 filter block combination); the sample was excited at $488 \mathrm{~nm}$ and $568 \mathrm{~nm}$ and detected from $585-$ infinite $\mathrm{nm}$ and $506-538 \mathrm{~nm}$. The biofilm thickness was measured by focusing through the biofilm from the solid-air interface to the metal surface, and averaging five or six positions for each coupon (17 coupons were tested). The images were processed with the National Institutes of Health Image 1.6 and Adobe Photoshop 5.5 (Adobe, San Jose, CA, USA). Z-section images (single image of the sectioning plane parallel to the metal surface) and vertical section images (a collection of images orthogonal to the metal surface at one position) were obtained.

\section{RESULTS}

\section{Effect of furanone on growth}

Furanone strongly affected the growth of $B$. subtilis on LB agar plates (Table 1) in a concentration-dependent manner; $52 \mu \mathrm{g} \mathrm{cm}^{-2}$ furanone completely inhibited growth in $48 \mathrm{~h}$. Inhibition of growth was also seen in suspension cultures (Table 2). At 0 and $10 \mu \mathrm{g} \mathrm{ml}^{-1}$ furanone, the cultures grew immediately after inoculation, although $10 \mu \mathrm{g} \mathrm{ml}^{-1}$ furanone caused a $28 \%$ decrease in the specific growth rate. At a concentration of $20 \mu \mathrm{g} \mathrm{ml}^{-1}$ furanone, the lag phase was extended significantly (about $13 \mathrm{~h}$ ), and the specific growth rate was decreased by $36 \%$ compared with that of the control. At a concentration of $40 \mu \mathrm{g} \mathrm{ml}^{-1}$, furanone inhibited growth completely (no growth obtained in $24 \mathrm{~h}$ ).

\section{Effect of furanone on swarming motility}

The swarming motility of $B$. subtilis was highly reproducible, and the morphology of the swarming colonies was consistent with that reported previously (Allison and

Table 1 Effect of furanone on colony growth of Bacillus subtilis

\begin{tabular}{lllll}
\hline \multirow{5}{*}{ Time (h) } & \multicolumn{4}{l}{$\begin{array}{l}\text { Colony diameter }(\mathrm{mm}) \\
\text { Concentration of furanone }\left(\mu \mathrm{g} / \mathrm{cm}^{2}\right)\end{array}$} \\
\cline { 2 - 5 } & 0 & 13 & 26 & 52 \\
\hline 0 & $\mathrm{NG}$ & $\mathrm{NG}$ & $\mathrm{NG}$ & $\mathrm{NG}$ \\
24 & $8 \cdot 3 \pm 0 \cdot 3$ & $2 \cdot 0 \pm 1 \cdot 0$ & $\mathrm{NG}$ & $\mathrm{NG}$ \\
48 & $15 \cdot 2 \pm 0 \cdot 3$ & $9 \cdot 3 \pm 1 \cdot 2$ & $8 \cdot 5 \pm 0 \cdot 5$ & $0 \cdot 5 \pm 0 \cdot 5$ \\
72 & $24 \cdot 3 \pm 1 \cdot 2$ & $15 \cdot 7 \pm 1 \cdot 5$ & $13 \cdot 0 \pm 0$ & $9 \cdot 0 \pm 0$ \\
\hline
\end{tabular}

土: Standard deviation; NG: no growth. 
Table 2 Effect of furanone on the growth rate of planktonic (suspension) cells and on the biofilm formation of Bacillus subtilis

\begin{tabular}{|c|c|c|c|c|}
\hline \multirow[b]{2}{*}{$\begin{array}{l}\text { Furanone concentration } \\
\left(\mu \mathrm{g} \mathrm{ml}^{-1}\right)\end{array}$} & \multicolumn{2}{|l|}{ Growth rate } & \multicolumn{2}{|l|}{ Biofilm formation } \\
\hline & $\begin{array}{l}\mu \\
\left(\mathrm{h}^{-1}\right)\end{array}$ & $\begin{array}{l}\text { Lag period } \\
\text { (h) }\end{array}$ & $\begin{array}{l}\text { Thickness of biofilm } \\
(\mu \mathrm{m})\end{array}$ & $\begin{array}{l}\text { Percentage of live cells } \\
\text { in the biofilm }\end{array}$ \\
\hline 0 & $1.71 \pm 0.09$ & 0 & $14 \pm 1$ & $82 \cdot 7$ \\
\hline 10 & $1 \cdot 23 \pm 0 \cdot 03$ & 0 & ND & ND \\
\hline 20 & $1.09 \pm 0.01$ & 13 & $13 \pm 2$ & $77 \cdot 2$ \\
\hline
\end{tabular}

土: Standard deviation; ND: not determined.

Hughes 1991). Fourteen hours after inoculation, colonies without furanone began to swarm at a rate of $0 \cdot 3 \mu \mathrm{m} \mathrm{s}{ }^{-1}$ (average speed of active and quiescent phases of growth), which is similar to previous reports (around $0.41 \mu \mathrm{m} \mathrm{s}^{-1}$ ) (Mendelson and Salhi 1996). However, the presence of furanone reduced the swarming speed in a concentrationdependent manner (Fig. 2), with 99.9\% swarming inhibited at $52 \mu \mathrm{g} \mathrm{cm}^{-2}$. The swarming speed of the colonies with furanone was $0.24 \mu \mathrm{m} \mathrm{s}^{-1}\left(13 \mu \mathrm{g} \mathrm{cm}^{-2}\right.$ furanone), $0.12 \mu \mathrm{m} \mathrm{s}^{-1}$ (26 $\mu \mathrm{g} \mathrm{cm}^{-2}$ furanone) and $0 \mu \mathrm{m} \mathrm{s}^{-1}\left(52 \mu \mathrm{g} \mathrm{cm}{ }^{-2}\right.$ furanone) (Fig. 2). Furanone at $52 \mu \mathrm{g} \mathrm{cm}^{-2}$ inhibited swarming completely, but growth was still present as evidenced by the slow increase in colony size $26 \mathrm{~h}$ after inoculation (Fig. 2). The shape of the colonies with furanone was very similar to that of the colonies without furanone (Fig. 3a). In addition, a high concentration of furanone was also tested; $250 \mu \mathrm{g} \mathrm{cm}$ furanone inhibited not only swarming but also growth, as no growth appeared after 3 days (the inoculated colonies did not expand). Streaking the inoculated cells on a LB plate indicated that the cells were dead. This is consistent with the growth rate experiment in that furanone inhibited the growth of $B$. subtilis with a concentration as low as

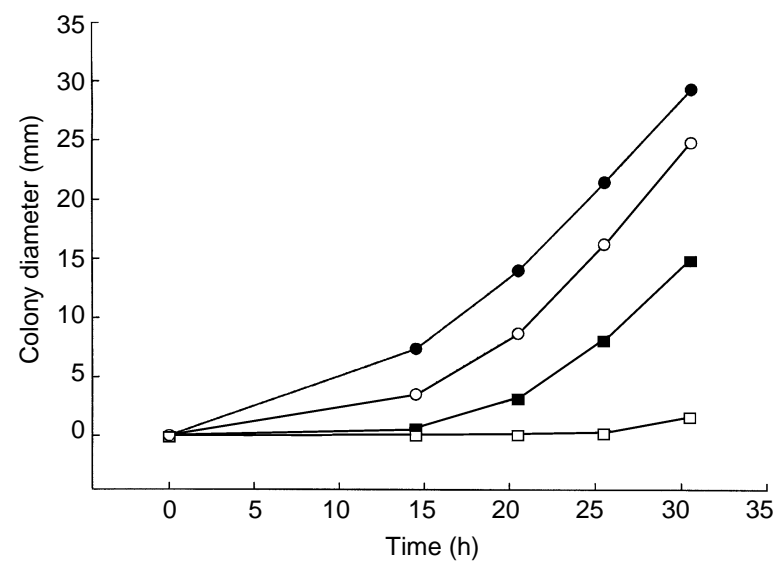

Fig. 2 Colony swarming of Bacillus subtilis in the presence of furanone (increasing colony diameter with time). (O) Control; $(\bigcirc)$

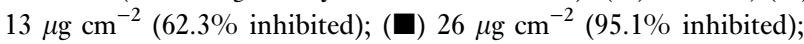
( $\square) 52 \mu \mathrm{g} \mathrm{cm}^{-2}$ (99.9\% inhibited)
$13 \mu \mathrm{g} \mathrm{cm}^{-2}$. However, when the B. subtilis colony that began swarming on the side of the plate without furanone entered the furanone-containing area, its swarming was not affected (Fig. 3b,c). This suggested that the swarming colony is more resistant to furanone once swarming is initiated.

It should be noted that the furanone was only added to a small region of the top of the agar plate $(40 \mu \mathrm{l}$ dichloromethane formed a $1.7 \mathrm{~cm}^{2}$ round layer), so the swarming speed can only be calculated with the initial part of the curves when the colonies were young (Fig. 2). Once the swarming colonies matured (both within and without the furanonecontaining zone), the swarming speed increased almost to the speed of a swarming colony in the absence of furanone. This further indicates that mature swarming colonies are more resistant to furanone.

\section{Effect of furanone on biofilm formation}

Using confocal scanning laser microscopy, it was observed that 20 and $40 \mu \mathrm{g} \mathrm{ml}^{-1}$ furanone caused a $5.6 \%$ and $25 \%$ decrease in the biofilm thickness, respectively (Table 2). In addition, $20 \mu \mathrm{g} \mathrm{ml}^{-1}$ furanone did not significantly affect the ratio of live to dead cells in the biofilm (reduced by $6.7 \%$ ), while $40 \mu \mathrm{g} \mathrm{ml}^{-1}$ decreased the percentage of live cells by $63 \%$ compared with the control (no furanone, Table 2). Vertical sections of the biofilm indicated no change in the biofilm structure with 0 and $20 \mu \mathrm{g} \mathrm{ml}^{-1}$ furanone, and the water channels could be seen clearly (dark area between the cell clusters). At $40 \mu \mathrm{g} \mathrm{ml}^{-1}$, the water channels began to collapse (Fig. 4). Hence, furanone affects B. subtilis biofilm formation significantly. Interestingly, $40 \mu \mathrm{g} \mathrm{ml}{ }^{-1}$ furanone completely inhibited the growth of $B$. subtilis in shake flasks (no growth in $24 \mathrm{~h}$ ), while it did not completely prevent biofilm formation. However, $60 \mu \mathrm{g} \mathrm{ml}^{-1}$ furanone inhibited biofilm formation completely (data not shown).

\section{DISCUSSION}

Besides swarming, swimming is an important mechanism for bacterial surface translocation (Allison and Hughes 1991). At 

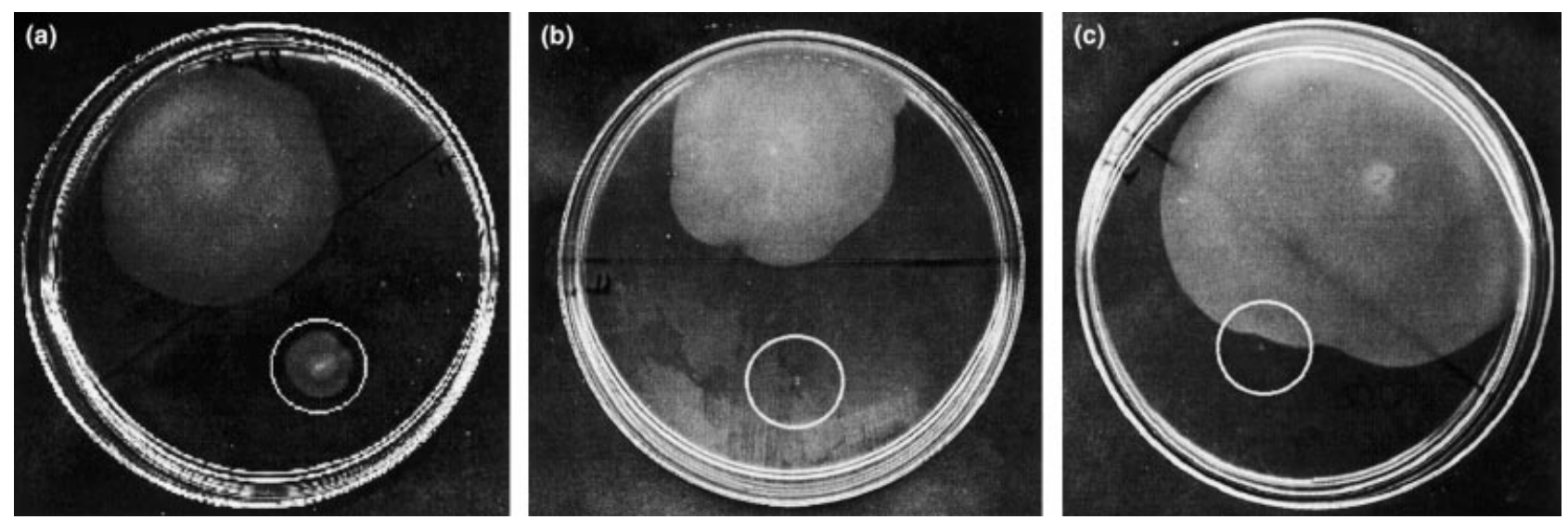

Fig. 3 Effect of furanone on the swarming motility of Bacillus subtilis (the circle indicates the area in which furanone was added). (a) $52 \mu \mathrm{g} \mathrm{cm}^{-2}$ furanone, $40 \mathrm{~h}$ after inoculation; (b) $250 \mu \mathrm{g} \mathrm{cm}{ }^{-2}$ furanone, $40 \mathrm{~h}$ after inoculation; (c) $250 \mu \mathrm{g} \mathrm{cm}{ }^{-2}$ furanone, $70 \mathrm{~h}$ after inoculation

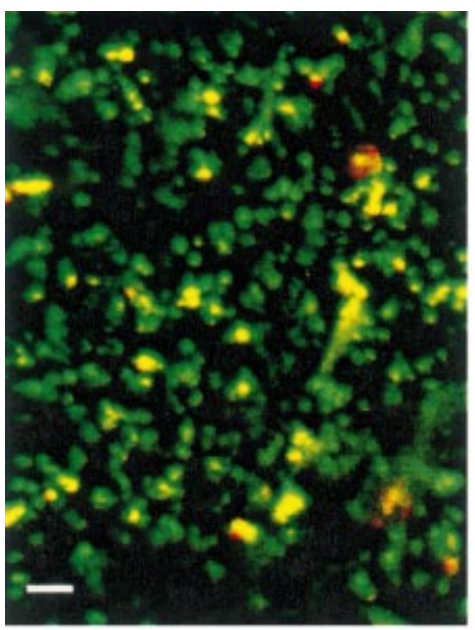

A1

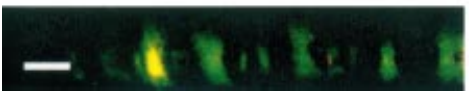

A2

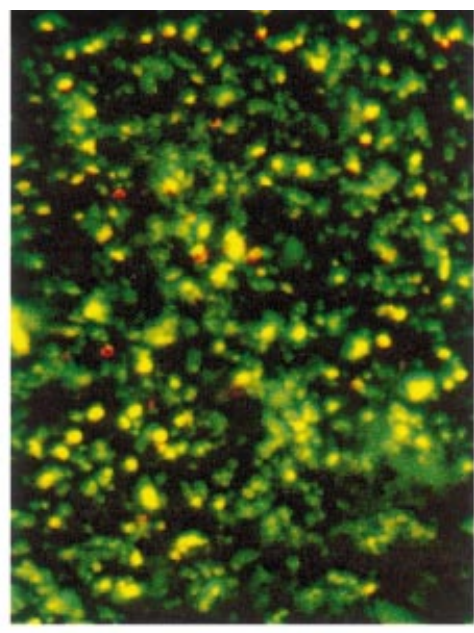

B1

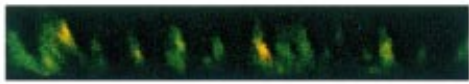

B2

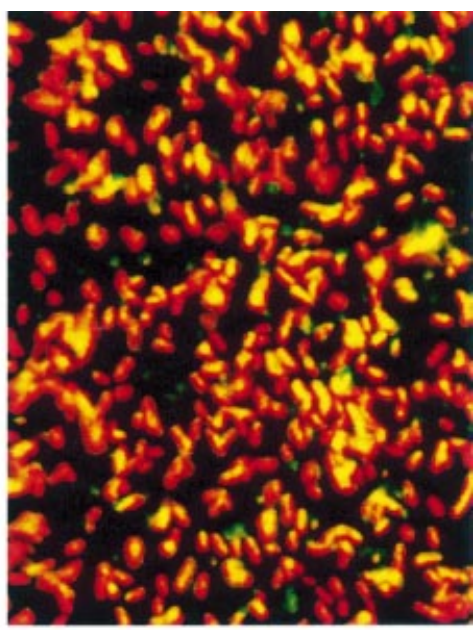

C1

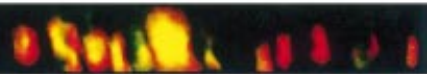

$\mathrm{C} 2$

Fig. 4 Effect of furanone on the Bacillus subtilis biofilm (representative confocal images). Bar $=10 \mu \mathrm{m}$. A1 ( $\mathrm{Z}$ section, i.e. planar view at top of the biofilm at water interface) and A2 (vertical section, i.e. biofilm viewed on edge by compiling $Z$ sections), no furanone; B1 ( $Z$ section) and B2 (vertical section), $20 \mu \mathrm{g} \mathrm{ml}^{-1}$ furanone; $\mathrm{C} 1$ (Z section) and C2 (vertical section), $40 \mu \mathrm{g} \mathrm{ml}^{-1}$ furanone. Live cells were stained green and dead cells were stained red using the Baclit viability kit. The void spaces between cell clusters are water-filled channels for nutrient and waste transfer (Lawrence $e t$ al. 1991; Kolter and Losick 1998)

low agar concentrations, cells swim through water-filled channels and form colonies with morphologies similar to those of chemotactic rings (Eberl et al. 1996a). Swimming is the result of rotation of the bacterial flagella rotor and is not a multicellular behaviour (Moat and Foster 1995). After investigating its behaviour on LB plates of different agar concentrations, B. subtilis was found to be capable of swimming at agar concentrations lower than $0.3 \%$, and of swarming on $0.4 \%$ agar plates. Hence, swimming behaviour was eliminated by controlling the agar concentration. The 
non-fractal morphology of the swarming colonies obtained here agrees well with that reported previously (Allison and Hughes 1991). Since the furanone was dissolved in dichloromethane before adding to the swarming plates, experiments were conducted to study the effect of dichloromethane on swarming, and no effect was found (data not shown). From the results of this study, it can be seen that furanone strongly inhibits the swarming of $B$. subtilis.

Bacillus subtilis is predicted to produce, via the LuxS synthase, a quorum sensing signal, AI-2 (Surette et al. 1999), and this AI-2 probably has a structure related to that of furanone (Chen et al. 2002). Since the brominated furanone used in this study has been shown to inhibit quorum sensing based on AI-2 (Ren et al. 2001), it probably inhibits swarming and biofilm formation of $B$. subtilis not only by suppression of growth but also by interfering with quorum sensing. However, it has not been possible to discriminate between these two possible effects. Given that the furanone has been shown to inhibit the growth of Grampositive bacteria at a concentration that is non-toxic to mammalian cells (Kjelleberg 1998), it has potential as an antimicrobial agent. This study therefore provides preliminary information for the potential use of furanone to inhibit the multicellular behaviour of Gram-positive bacteria. The increased resistance to furanone exhibited by $B$. subtilis swarming colonies and biofilm suggests that it may be advantageous to combine furanone with other antibiotics for better performance. In addition, modifying the structure of natural furanone may make it more efficient.

\section{ACKNOWLEDGEMENTS}

The authors thank Prof. David Knecht for assistance with confocal scanning laser microscopy. The assistance of Mr Xing Dong (NMR analysis) and Mr Haihu Qin (IR analysis) is also appreciated.

\section{REFERENCES}

Allison, C., Coleman, N., Jones, P.L. and Hughes, C. (1992) Ability of Proteus mirabilis to invade human urothelial cells is coupled to motility and swarming differentiation. Infection and Immunity 60, $4740-4746$.

Allison, C. and Hughes, C. (1991) Bacterial swarming: an example of prokaryotic differentiation and multicellular behaviour. Science Progress Edinburgh 75, 403-422.

Bassler, B.L. (1999) How bacteria talk to each other: regulation of gene expression by quorum sensing. Current Opinions in Microbiology 2, 582-587.

Bassler, B.L., Greenberg, E.P. and Stevens, A.M. (1997) Cross-species induction of luminescence in the quorum-sensing bacterium Vibrio harveyi. Journal of Bacteriology 179, 4043-4045.

Beechan, C.M. and Sims, J.J. (1979) The first synthesis of fimbrolides, a novel class of halogenated lactones naturally occurring in the red seaweed Delisea fimbriata (Bonnemaisoniaceae). Tetrahedron Letters 19, 1649-1652.

Cao, J. and Meighen, E.A. (1989) Purification and structural identification of an autoinducer for the luminescence system of Vibrio harveyi. Fournal of Biological Chemistry 264, 21670-21676.

Chen, X., Schauder, S., Potier, N. and Hughson, F.M. (2002) Structural identification of a bacterial quorum-sensing signal containing boron. Nature 415, 545-549.

Crowe, M., Ispahani, P., Humphreys, H., Kelley, T. and Winter, R. (1998) Bacteraemia in the adult intensive care unit of a teaching hospital in Nottingham, UK, 1985-1996. European Fournal of Clinical Microbiological Infection and Disease 17, 377-384.

Davies, D.G., Parsek, M.R., Pearson, J.P., Iglewski, B.H., Costerton, J.W. and Greenberg, E.P. (1998) The involvement of cell-to-cell signals in the development of a bacterial biofilm. Science 280, 295-298.

Eberl, L., Christiansen, G., Molin, S. and Givskov, M. (1996a) Differentiation of Serratia liquefaciens into swarm cells is controlled by the expression of the $f h D$ master operon. Fournal of Bacteriology 178, 554-559.

Eberl, L., Winson, M.K., Sternberg, C. et al. (1996b) Involvement of $\mathrm{N}$-acyl-L-homoserine lactone autoinducers in controlling the multicellular behaviour of Serratia liquefaciens. Molecular Microbiology 20, 127-136.

Edmond, M.B., Wallace, S.E., McClish, D.K., Pfaller, M.A., Jones, R.N. and Wenzel, R.P. (1999) Nosocomial bloodstream infections in United States hospitals: a three-year analysis. Clinical Infectious Diseases 29, 239-244.

Elvers, K.T. and Lappin-Scott, H.M. (2000) Encyclopedia of Microbiology. ed. Lederberg, J. San Diego, California: Academic Press.

Freeman, J.A. and Bassler, B.L. (1999) A genetic analysis of the function of LuxO, a two-component response regulator involved in quorum sensing in Vibrio harveyi. Molecular Microbiology 31, 665-677.

Fujikawa, H. (1994) Diversity of the growth patterns of Bacillus subtilis colonies on agar plates. FEMS Microbiology Ecology 13, 159-168.

Givskov, M., de Nys, R., Manefield, M. et al. (1996) Eukaryotic interference with homoserine lactone-mediated prokaryotic signaling. Fournal of Bacteriology 178, 6618-6622.

Gram, L., de Nys, R., Maximilien, R., Givskov, M., Steinberg, P. and Kjelleberg, S. (1996) Inhibitory effects of secondary metabolites from the red alga Delisea pulchra on swarming motility of Proteus mirabilis. Applied and Environmental Microbiology 62, 4284-4287.

Jayaraman, A., Cheng, E.T., Earthman, J.C. and Wood, T.K. (1997) Importance of biofilm formation for corrosion inhibition of $\mathrm{SAE}$ 1018 steel by pure-culture aerobic biofilm. Fournal of Industrial Microbiology and Biotechnology 18, 396-401.

Kjelleberg, S. (1998) Inhibition of Gram positive bacteria. International patent WO 99/53915.

Kolter, R. and Losick, R. (1998) One for all and all for one. Science $\mathbf{2 8 0}$, 226-227.

Kumar, A.V.R., Singh, R. and Nigam, R.K. (1999) Mossbauer spectroscopy of corrosion products of mild steel due to microbiologically influenced corrosion. Fournal of Radioanalytical and Nuclear Chemistry 242, 131-137.

Lawrence, J.R., Korber, D.R., Hoyle, B.D., Costerton, J.W. and Caldwell, D.E. (1991) Optical sectioning of microbial biofilms. Journal of Bacteriology 173, 6558-6567. 
Manny, A.J., Kjelleberg, S., Kumar, N., de Nys, R., Read, R.W. and Steinberg, P. (1997) Reinvestigation of the sulfuric acid-catalysed cyclisation of brominated 2-alkyllevulinic acids to 3-alkyl-5-methylene-2 (5H)-furanones. Tetrahedron 53, 15813-15826.

Mendelson, N.H. and Salhi, B. (1996) Patterns of reporter gene expression in the phase diagram of Bacillus subtilis colony forms. Journal of Bacteriology 178, 1980-1989.

Moat, A.G. and Foster, J.W. (1995) Microbial Physiology. New York: Wiley-Liss.

Nagarajan, V., Albertson, H., Chen, M. and Ribbe, J. (1992) Modular expression and secretion vectors for Bacillus subtilis. Gene 114, 121-126.

Ren, D., Sims, J.J. and Wood, T.K. (2001) Inhibition of biofilm formation and swarming of Escherichia coli by (5Z)-4-Bromo-5(Bromomethylene)-3-Butyl-2(5H)-Furanone. Environmental Microbiology 3, 731-736.
Schauder, S., Shokat, K., Surette, M.G. and Bassler, B.L. (2001) The LuxS-family of bacterial autoinducers: biosynthesis of a novel quorum-sensing signal molecule. Molecular Microbiology 41, $463-476$.

Surette, M.G. and Bassler, B.L. (1998) Quorum sensing in Escherichia coli and Salmonella typhinurium. Proceedings of the National Academy of Sciences USA 95, 7046-7050.

Surette, M.G., Miller, M.B. and Bassler, B.L. (1999) Quorum sensing in Escherichia coli, Salmonella typhimurium, and Vibrio harveyi: a new family of genes responsible for autoinducer production. Proceedings of the National Academy of Sciences USA 96, 1639-1644.

Thampuran, N. and Surendran, P.K. (1996) Effect of chemical agents on swarming of Bacillus species. Fournal of Applied Bacteriology 80, 296-302. 